\title{
Procedural justice, posturing and defiant action: Exploring prisoner reactions to prison authority
}

\author{
Julie M. Barkworth \& Kristina Murphy
}

Griffith Criminology Institute, Griffith University, Brisbane, Australia

Julie Barkworth (i.barkworth@griffith.edu.au); Ph: +61 737351089

Dr Julie Barkworth is a Lecturer in the School of Criminology and Criminal Justice and Griffith Criminology Institute at Griffith University. Julie's research interests include procedural justice; cooperation and compliance behaviour; defiance and resistance to authority; policing; policing vulnerable communities; corrections; prisoner well-being.

Kristina Murphy is a professor of criminology at the Griffith Criminology Institute at Griffith University and is an Australian Research Council Future Fellow. Kristina's expertise centres on procedural justice and its impact on the perceived legitimacy of criminal justice institutions and people's willingness to cooperate and comply with authorities. Kristina has had a number of research grants examining the impact of procedural justice policing on vulnerable communities.

Submitted to: Justice Quarterly

Date: 12 December, 2018

Word count: 12,163 (48 pages) 


\title{
Procedural justice, posturing and defiant action: Exploring prisoner reactions to prison authority
}

\begin{abstract}
Prison staff are vital for enforcing order in prisons. However, order is not only maintained by what prison staff do, but also relies on prisoners willingly following the directives of prison staff and complying with prison rules and procedures. This paper puts forward the idea that how prison staff treat prisoners can affect the social distancing prisoners put between themselves and prison staff, potentially making defiance and noncompliance more difficult to manage. Social distancing is operationalised in this paper as motivational posturing (Braithwaite, 2003). Using survey responses from 177 Australian prisoners, the paper shows a strong association between prisoners' perceptions of procedural justice in prison and their self-reported compliance with prison rules. It also shows for the first time that motivational postures exist in a corrections context, and are associated with both procedural justice perceptions and self-reported compliance behaviour. Postures are also found to mediate the procedural justice/compliance relationship.
\end{abstract}

Keywords: Procedural Justice, Motivational Postures, Defiance, Compliance, Corrections 


\section{Introduction}

Numerous scholars argue that order in prisons is predominantly the outcome of fear, coercion, and threats of violence (e.g., Scraton, Sim \& Skidmore, 1991; see also Sparks, Bottoms \& Hay, 1996); a by-product of prison order being based on a model of deterrence. Tyler (2006) argues that a deterrence-based model of behaviour is instrumental in nature. Here, behaviour is shaped by peoples' self-interest and compliance with rules and laws is based on associated incentives and penalties, and potential personal gains and losses. While deterrence is likely to be important in the prison context, some scholars argue that prisoners will be more likely to comply with prison rules because of a belief that the prison regime and its staff are legitimate and entitled to be obeyed; not because they fear the consequences of being non-compliant (see Jackson, Tyler, Bradford, Taylor \& Shiner, 2010; Reisig \& Mesko, 2009). While deterrence is sometimes necessary and certainly has its place in the prison environment, we suggest that a more effective approach to maintaining order in prisons is one that fosters prisoners' acceptance of rules and their voluntary compliance with those rules. According to this type of model of behaviour, compliance is normative in nature. Compliance is forthcoming when people view authorities in a positive light. Here, people also comply with rules and laws because they view them as just and moral, and because they feel personally committed to following those rules and laws, regardless of the risk of punishment for not doing so. The suggestion that a normative model of behaviour might offer better compliance outcomes than an instrumental model is not new to the criminology literature. In fact, many scholars argue that order and compliance can be best achieved through fair decision-making and fair treatment of offenders (Jackson et al., 2010; Murphy, 2008; Tyler, 1990). Specifically, research undertaken across a range of regulatory contexts has demonstrated that if authorities adopt procedural justice practices in their dealings with those they govern it can be influential in reducing defiance, while increasing willing compliance with authorities and rules (e.g., Ayres 
\& J. Braithwaite, 1992; Barkworth \& Murphy, 2015; J. Braithwaite \& Makkai, 1994; Jackson et al., 2012; Murphy, 2005; Murphy, Mazerolle \& Bennett, 2014; Murphy \& Tyler, 2008; Tyler \& Huo, 2002).

Procedural justice is displayed when authorities are perceived to be trustworthy, are seen to be acting with neutrality, when they treat people with respect and dignity, and when they allow people the opportunity to participate and express their viewpoints (i.e., voice) before decisions are made (Mazerolle et al., 2014). It has been theorised that procedural justice is important to people and can have positive effects on their pro-social behaviours because when people are respected by authorities, it reaffirms their identity with a group's authority, their status as a valued member of a society, and reinforces their belief that an authority is entitled to be obeyed (Tyler \& Lind, 1992). People are more likely to support and comply with a group authority's norms (such as obeying their rules and laws) when they feel a stronger connection to that group (e.g., prison staff) (Tyler \& Lind, 1992).

The question at hand is for whom procedural justice will be most effective within a prison context. Prisons contain individuals who generally show contempt for rules and laws; this is how they ended up in prison in the first place. Once incarcerated, many prisoners also disengage from prison staff, making attempts to engage positively with those prisoners more difficult. An emerging body of international research has shown that prisoners can and do respond positively to procedural justice; however, only a limited number of studies have been conducted so far, in English, Dutch, Canadian, American and Slovenian prisons (e.g., Biejersbergen, Dirkzwager, Eichelsheim, Van der Laan \& Nieuwbeerta, 2014, 2015; Biejersbergen, Dirkzwager \& Nieuwbeerta, 2016; Brunton-Smith \& McCarthy, 2016; Hacin \& Mesko, 2018; Jenness \& Calavita, 2018; Reisig \& Mesko, 2009; Weinrath, 2016). Predominantly utilising surveys of prisoners, these studies reveal that prisoners are more likely to view the prison regime and its staff as legitimate, and are more likely to comply with prison 
rules and with prison officers if they believe staff use procedural justice in their dealings with prisoners. The value of this research is that it suggests that compliance from prisoners can be voluntarily extended through procedural justice because it enhances the perceived legitimacy of prison staff. As will be discussed in more depth in the coming sections, the current study attempts to extend this previous research by focusing not on prisoners' legitimacy perceptions, but on the social distancing they place between themselves and prison staff.

We know from non-prison research that procedural justice effects can vary between and within groups, contexts, and over time according to the direct and indirect experiences people have with authorities (Braithwaite, 2009; Braithwaite, Murphy \& Reinhart 2007; Herbert, 2006; Madon, Murphy \& Sargeant, 2017; Murphy, 2017; Murphy \& Cherney, 2011, 2012; Sargeant, Murphy \& Cherney, 2014; Weitzer, 2006; Weitzer \& Brunson, 2009). In some contexts, procedural justice has been found to be ineffective or counter-productive (V. Braithwaite et al., 2007; Murphy \& Cherney, 2011). The purpose of the current paper is to introduce to the corrections literature a new theoretical framework developed in noncorrectional contexts to better understand when and why different types of prisoners will be receptive to procedurally just treatment from prison staff. To clarify, this study does not attempt to examine whether procedural justice shapes compliance behaviours through the mediating influence of legitimacy; but rather, how motivational posturing styles interact with perceptions of procedural justice to influence prisoners' compliance-related behaviours. Before proceeding to discuss the aims of the current study, the following section will first introduce Braithwaite's (2009) Theory of Defiance and will discuss how defiance and non-compliance manifests in prison. This will be followed by a brief discussion about how procedural justice might influence prisoners' compliance behaviour through reducing prisoners' defiant postures. 


\section{A new theoretical framework for corrections: Motivational postures and defiant action}

Braithwaite's (2009) Theory of Defiance attempts to understand how and why individuals react the way they do toward authorities, and how they subsequently manage their encounters with authorities. Braithwaite developed her framework after years of research to understand defiance and non-compliance in the nursing home and taxation contexts. The framework has since been applied in the policing (Murphy, 2016; Sargeant, Murphy \& Madon, 2018), child protection (Harris \& Gosnell, 2012) and environmental regulation (Bartel \& Barclay, 2011) contexts, but until now has not been considered in a corrections context. We argue it has salience in a corrections context because it incorporates similar ideas that have been raised by various corrections scholars about prisoner behaviour, but does so in one overarching framework.

Central to Braithwaite's (2009) theory is the concept of social distancing. Braithwaite argues that individuals evaluate authorities in terms of how they perform, what they stand for, whether they pose a threat to an individual's identity or goals, and whether authorities and their rules align with their own value system. Over time, these evaluations are revised or shared with others, and people come to develop a psychological posture in relation to the authority. This posturing can be positive or negative and reflects the degree of social distancing people place between themselves and authority. In other words, social distancing reflects the degree of voluntary contact individuals are willing to entertain with an authority; those who place greater social distance between themselves and authority are more likely to hold negative attitudes towards those authorities and their rules and are more likely to display defiance. In contrast, social distancing is minimal when people want to align themselves with an authority and agree with their overall mission or purpose (Braithwaite 2009). The concept of social distancing is similar to Gamson's (1968) idea of 'alienation', where individuals fall somewhere along the continuum of engagement (support for a system) to disengagement (alienation from a system). 
However, Braithwaite's notion of social distancing is more dynamic and multidimensional than Gamson's alienation continuum. She argues that people do not simply adopt one position toward authorities, but instead can display different types of positions based on the circumstances at the time. These 'positions' are what Braithwaite refers to as motivational posturing.

Importantly, motivational postures have been found to be precursors to compliant or non-compliant behaviour (Braithwaite, 2003, 2009). Five motivational postures have been identified in Braithwaite's research: commitment, capitulation, resistance, disengagement, and game-playing (see Braithwaite, 1995, 2003; Braithwaite, Braithwaite, Gibson \& Makkai, 1994). Those who display the postures of commitment and capitulation place less social distance between themselves and an authority. Braithwaite argues that these postures disable the prospect of defiance and non-compliance. Resistance, disengagement and game-playing, on the other hand, reflect greater social distance; they are considered enablers of defiance, and may subsequently lead to non-compliant behaviour.

From a regulator's perspective, both commitment and capitulation lead to the same outcome (i.e., compliance), but from the perspective of the regulated, the motivation for doing so is different. Commitment relates to an individual's willingness to do the right thing. Committed individuals embrace the overall purpose of an authority; they are committed to the system and its goals, and feel morally obligated to follow the rules and directions of that authority or system. In the context of a prison, a committed prisoner would voluntarily comply with prison staff and prison rules and procedures because they believe it is right to do so and they feel obligated to follow staff or those rules.

Capitulation to an authority, in contrast, sees individuals complying with authorities, not out of a sense of belief or value in the system that the authority represents, but rather as a 
"keep them happy" philosophy (Braithwaite, 2009, p.38). Capitulated individuals see compliance as the easier action to take, serving their best interests in the long run by not standing out to the authority through defiance. For example, prisoners who display a capitulation posture may only follow prison rules and staff directives to avoid conflict that could end negatively for them. This is not unlike Carrabine's (2005) argument that prisoners comply not necessarily because they feel prison authorities should be obeyed but because of fear, which can lead to pseudo conformity. Similarly, Crewe (2007) suggests prisoners might remain silent and comply with prison officer directives as well as comply with the requirements of their sentence while not necessarily agreeing with the conditions or processes of their incarceration. In this sense, prisoners set out to progress through the system as quickly as possible and serve their time problem-free, rather than having a genuine commitment to the system they are involuntarily confined to.

Resistance, disengagement and game-playing are all defiance-related postures which fall into two broad categories: resistant defiance (i.e., resistance) and dismissive defiance (i.e., disengagement and game-playing). According to Braithwaite (2009), resistant defiance involves speaking out against an authority when in disagreement with their use of power. Resisters want to be heard, they want to be given 'voice', and they want the authority to be aware of problems and make improvements to the way they do things. Resistant defiance does not result from a desire to destabilise a system, but is a way of communicating dissatisfaction with processes and policies, or treatment viewed as unfair. Resistant defiance may manifest as name-calling, refusing to follow directives, or through actual physical resistance (Terrill, 2003). Resistance in a prison context may also be displayed through what Cohen and Taylor (1972) refer to as 'campaigning' and 'direct confrontation'. Campaigning refers to prisoners' attempts to improve prison conditions and reduce deprivations by appealing to state and national government bodies. Direct confrontation, on the other hand, occurs when groups 
fighting for the same causes or outcomes are united and are able to take on an authority in solidarity (e.g., through disturbances and riots within the prison walls, or staging protests on prison rooftops).

Dismissive defiance, in contrast to resistant defiance, goes further in terms of oppositional intention whereby individuals "appear to be stepping outside or transcending the constraints of the regulatory institution" (Braithwaite, 2009, p.39). Disengagement is one form of dismissive defiance. It involves detaching one's self from authority or a system and displaying apathy toward being punished (Braithwaite, 1995, 2001, 2009). Disengaged individuals simply dismiss or ignore the demands and threats of an authority, with disengagement often displayed through withdrawal or avoidance behaviour. In noncorrectional contexts, disengagement is generally displayed by avoiding all contact with an authority. However, this cannot be achieved in a prison environment where prisoners and prison staff must engage on a daily basis. In a prison environment, disengagement may come across as apathy or by individuals simply placing greater physical distance between themselves and prison staff. Cohen and Taylor (1972) suggest that long-term prisoners (i.e., serving 25 years to life) are likely to disengage or retreat from others as a way to adapt to prison life.

Game-playing, the second dismissive defiant posture, combines the attitude of a disengager with the "can do" attitude of someone who thinks they can beat the authority at their own game (Braithwaite, 2001, 2009). Rather than outright ignore the demands of authority, however, game-players take pleasure in finding ways to get around or redefine rules. Individuals must have an informed understanding of the regulatory code and how the system works in order to 'play the game'. To game-players, authorities are seen as competitors or sparring partners (challengers) in the game they are playing, rather than as agents of disapproval to be obeyed (or disobeyed) (Braithwaite, 2009). 
McDermott and King (1988) first described imprisonment as a series of 'mind games' when they published findings from their examination of the prison system in England and Wales. They suggested that how well someone 'plays the game' of prison life has much to do with their knowledge of formal and informal rules and their ability to skilfully use that knowledge to their own advantage. McDermott and King (1988) argued prisoners can engage in games that involve taking advantage of and manipulating staff to form inappropriate relationships which may assist in trafficking contraband into the prison and receiving favourable psychological and behavioural reports. They can also play a number of mind games to overcome boredom through finding ways to obtain additional time in or out of their cell, to protect themselves by reporting on other prisoners' behaviour or illegal activities, or by manipulating the system to secure a transfer to a more favourable prison, or from mainstream to protection, or secure to residential. McIlwain (2004) further suggested prisoners can sometimes identify vulnerable staff, and will subsequently 'groom' staff to commit minor transgressions to official misconduct. ${ }^{1}$

If we return to our note about the normative vs. instrumental models of compliance behaviour, commitment and capitulation might be considered more normative-based postures; people comply with authorities because they are committed to the system or its authorities and believe it is right to do so. Disengagement and game-playing are more instrumental in nature and may require authority intervention to comply. Resistance is less clear. People tend to resist because they are not happy with a process or the way an authority is behaving, not because they do not want to comply with that authority's rules and laws. When an individual becomes

\footnotetext{
${ }^{1}$ Braithwaite's (2009) defiance theory has been developed to look at how individuals respond psychologically to authorities and how authorities' actions and behaviour can have an impact on the behaviour displayed by the individual. In conjunction with what prisoners themselves believe is the right kind of behaviour to adopt in prison (i.e., the inmate code), prisons also have their own subcultures which might play a role in shaping prisoners' posturing and behaviour. While a discussion of the prison subculture literature is beyond the scope of the current paper, it is certainly possible the prison subculture may shape the posturing style displayed by prisoners.
} 
satisfied with the authority then compliance is forthcoming. In this sense, compliance will typically be forthcoming and is based on normative concerns. Fostering normative-based postures is therefore important for encouraging ongoing and voluntary compliance from prisoners. As noted earlier, while Braithwaite's five motivational postures have been identified and measured successfully in several different regulatory contexts (e.g., Bartel \& Barclay, 2011; V. Braithwaite et al., 2007; Harris \& Gosnell 2012; Murphy, 2016; Murphy \& Cherney, 2012), no study has yet sought to measure and establish their existence within a correctional context. The current study does so.

\section{Managing defiant postures: When might procedural justice work?}

The natural question that arises from Braithwaite's motivational posturing work is: How can regulators best manage different forms of defiance? This is an important question to ask because defiance is thought to be a precursor to non-compliant behaviour (Braithwaite, 2009; Sherman, 1993). To be effective, authorities (including prison staff) need to understand when a particular regulatory approach is likely to reduce defiance and when it is likely to exacerbate defiance. Procedural justice may seem like an attractive means by which to reduce defiance and increase voluntary compliance. However, procedural justice may not always be an effective strategy to reduce defiance and non-compliance. Also of interest to the current study is to explore if procedural justice is associated with prisoners' different motivational postures.

Braithwaite (2009) argues that procedural justice secures postures of commitment and capitulation. However, she also argues that resistant defiance is most likely to manifest when an individual is threatened by authorities. Braithwaite suggests that grievance and disillusionment can occur when authorities disregard procedural justice and rely purely on coercion. Stigmatising prisoners, being heavy-handed, and treating them disrespectfully is 
likely to breed contempt (J. Braithwaite, 1989; see also Ahmed, Harris, Braithwaite \& Braithwaite, 2001). This suggests that resistant defiance might be effectively reduced when authorities address the source of the grievance. Braithwaite (2013) argues that resistant defiance can be addressed through persuasion and consultation with the aggrieved party, and through respectful and fair treatment (i.e., procedural justice). She argues that when procedural justice is used to address the source of a grievance, resistance should subside and voluntary compliance with rules and directives should be forthcoming. In contrast, disengaged prisoners are unlikely to be interested in abiding by prison rules, and a game-player is likely to try to manipulate prison rules to serve their own interests. It is these two postures of defiance that pose the biggest problems for authorities and ones where procedural justice may not work. It is also important to acknowledge that prison staff may each have their own methods for successfully managing prisoners, which may vary between prisons (see Hacin, 2018). Prior research shows us that prisoners have different perceptions of staff use of procedural justice across prisons; specifically, 'open' prisons are viewed as more procedurally just than 'maximum security' prisons (see Hacin, 2018). While this is to be expected, what is important is that staff in different prisons be encouraged to support the principals underlying procedural justice.

A limited number of empirical studies have considered the effects of procedural justice on individuals who display different postures in contexts other than prison (e.g., taxation, policing). They have had mixed results. Early empirical studies of procedural justice and motivational posturing demonstrated authorities could reduce resistance through fair and respectful treatment (e.g., Braithwaite, 2009; J. Braithwaite, Makkai \& Braithwaite, 2007; V. Braithwaite et al., 2007; Hartner, Rechberger, Kirchler \& Schabmann, 2008; Murphy, 2003, 2005; Murphy, Tyler \& Curtis, 2009). For example, J. Braithwaite et al. (2007) found nursing home CEOs were more likely to shift from a resistance posture to commitment when regulators 
treated them with procedural justice, and were more likely to comply with nursing home regulations in the future. A study by Hartner et al. (2008) used self-report survey data from more than 2,000 Australian taxpayers to examine the role of procedural justice and motivational postures on tax compliance. They found that procedural justice was important for increasing postures of deference (i.e., commitment and capitulation) and for reducing postures of defiance (i.e., resistance, disengagement and game-playing). It was also found that the three postures of defiance were related to tax non-compliance and mediated the relationship between procedural justice and tax non-compliance.

V. Braithwaite et al. (2007), on the other hand, found that procedural justice could exacerbate dismissive defiance. She used data from 3,253 randomly selected Australian taxpayers and 2,292 taxpayers involved in a dispute with the tax authority. Taxpayers who considered the tax authority as procedurally just were less likely to display resistance toward directives of the authority and were more likely to express commitment with the authority. However, when taxpayers viewed the tax authority as using procedural justice, disengagement and game-playing postures were heightened. Braithwaite et al. offered two possible explanations for this latter finding: 1) procedural justice may be seen as a sign of weakness and a last attempt by the authority to regain some credibility; 2) people may see the authority as employing the principles of procedural justice with little integrity, using it instead to manipulate individuals to quickly resolve the conflict.

Finally, a recent study by Murphy (2016) further considered the influence of procedural justice on different posturing styles in both the taxation and policing contexts. Longitudinal survey data was collected from 659 taxpayers in a dispute with the Australian Taxation Office and from 1,190 Australian citizens who were asked about their experiences with the police. For both groups, procedural justice was associated with greater self-reported compliance with laws. Procedural justice was also effective for reducing resistance posturing over time (providing 
support for V. Braithwaite et al.'s (2007) findings), but disengagement remained unaffected over time. Murphy also demonstrated that holding a resistant posture mediated the effect of procedural justice on self-reported compliance behaviour. While these studies provide some background for the role of motivational posturing styles and their association with procedural justice and compliance, these posturing styles have not yet been examined in a corrections context. As such, it is unknown whether motivational postures will manifest in a prison environment, and if or how posturing styles are associated with prisoner perceptions of procedural justice and their compliance behaviour. Prisoners have significantly more contact with prison staff than taxpayers have with tax authorities or citizens have with police. It is therefore important to consider whether motivational posturing styles manifest differently in prisons and what role they may play in shaping compliance in this vastly different context.

\section{The Current Study}

Considering prison is an environment where residents are forced together in confinement against their will, the problem of defiance, order and control is constantly on the minds of those charged with maintaining it. Order is most easily maintained when defiance is absent. However, prisoners' decisions about whether or not to comply with prison rules are dependent on a range of individual and institutional factors (see Liebling, assisted by Arnold, 2004; Sparks et al., 1996). We propose that prisoners' perceptions of procedural justice in prison and the motivational postures that they adopt are two such individual-level factors likely to influence decisions to comply with prison authorities and their rules.

Prior prison research has established that prisoners' procedural justice perceptions are related to their legitimacy perceptions, and legitimacy perceptions are related to compliance behaviour (e.g., Brunton-Smith \& McCarthy, 2016; Hacin \& Mesko, 2018; Reisig \& Mesko, 2009). The current study does not intend to replicate these studies. Rather, it extends this 
research by offering an alternative framework for understanding the relationship between procedural justice and compliance through its focus on the psychological concept of social distancing and the psychological postures people adopt toward authority. Subsequently, the current study examines how procedural justice influences prisoners' motivational posturing styles and how the postures, in turn, influence compliance-related behaviour. The current study is therefore the first to establish whether Braithwaite's (2009) motivational posturing styles manifest in a prison environment. It also tests whether deferent or defiant postures mediate the relationship between prisoners' perceptions of procedural justice and their non-compliant behaviour. This paper is guided by three research questions.

RQ1: Do Braithwaite's (2009) five motivational postures emerge in a corrections context?

RQ2: Is the perceived use of procedural justice by prison staff related to prisoners' (a) five motivational posturing styles and (b) their self-reported compliance behaviour?

RQ3: Do motivational postures mediate the relationship between procedural justice and prisoners' self-reported compliance behaviour?

\section{Method}

\section{Participants and Procedure}

Data collection took place from February 2016 to February 2017 in four maximumsecurity prisons (three public, one private) within an Australian jurisdiction, representing 30\% of all prisons in that jurisdiction. The participating prisons ranged in capacity from $300-1000$ prisoners, and all often run at approximately $120 \%$ capacity. The Crime and Corruption Commission (CCC; 2018) reported a 90\% increase in the number of use of force incidents per 100 prisoners over the $2013 / 14$ to $2016 / 17$ period. Approximately $30 \%$ of allegations made against staff were regarding assault or excessive use of force, with such claims accounting for 
more than $10 \%$ of substantiated allegations (CCC, 2018). Such allegations suggest some degree of 'direct campaigning' and an attempt to improve prison conditions.

Approximately 600 of the 2,568 prisoners from the four prisons were asked if they were willing to participate in a self-report survey about their perceptions of prison staff. ${ }^{2}$ A total of 230 surveys were handed to prisoners who agreed to participate, with 181 surveys returned (response rate $=30.2 \%$; completion rate $=78.7 \%$ ). Previous prison studies in other countries have reported response rates ranging from 34\% to $89 \%$ (e.g., Brunton-Smith \& McCarthy, 2016; Reisig and Mesko, 2009; U.S. Bureau of Justice Statistics, 2011; Wooldredge, 1999), suggesting the response rate of the current study is quite low. The reason for the overall low response rate could be attributed to differences in recruiting prisoners from each of the participating centres. For example, in one of the centres where a member of the prison staff recruited participants (due to the insistence of the prison's management), the response rate was $16 \%$, while in one of the centres where the researcher was able to directly approach prisoners, the response rate was $89 \%$. Therefore, it may be that had the researcher been able to directly approach prisoners in all participating centres, the overall response rate may have been higher. After screening the survey data, two cases were removed due to significant amounts of missing data, and two cases were excluded based on response patterns that indicated the respondents had not carefully read the questions and responded accordingly. The final sample size consisted of 177 participants. As can be seen in Table 1, the final sample was generally representative when compared against all prisoners in that Australian jurisdiction.

\footnotetext{
${ }^{2}$ In the event participants indicated difficulty with literacy or understanding of terminology, the first author conducted the survey one-on-one, reading through the survey items, explaining concepts where needed, and marking the participants' responses on the survey. Only two participants required assistance in completing the survey. Literate participants completed the survey on their own.
} 


\section{Measures}

Demographic and control variables. Table 1 presents participants' demographic characteristics and information regarding their current sentence (Note: information about offence type was not collected due to ethics requirements). Age, education and time served were measured as continuous variables; a higher score on education reflects a higher level of completed education, and a higher score on time served reflects a longer period of time in prison to date (regardless of sentence length). The remaining variables were dummy-coded: ethnicity $(0=$ Indigenous; $1=$ Non-Indigenous $)$, marital status $(0=$ Unmarried; $1=$ Married $)$, sentenced $(0=$ Sentenced; $1=$ Remand $)$, first time in prison $(0=$ No; $1=$ Yes $)$, and prison type $(0=$ Private; $1=$ Public $)$.

Procedural justice. In the four participating prisons, prisoners and prison officers have regular, daily face-to-face contact, providing ample opportunity for prison officers to engage with prisoners in procedurally just ways. However, it should be noted that the measure of procedural justice in the current study does not reflect an actual experience of procedural justice, but rather measures prisoners' general perceptions regarding prison officer use of procedural justice. The 10-item measure of procedural justice reflected Tyler's (1990) fourelement model of procedural justice; it included measures of respect, neutrality, voice and trustworthiness. The specific measures were adapted from Murphy, Murphy and Mearn's (2010) research. A five-point Likert scale was used for all individual questions ( 1 = Strongly disagree to $5=$ Strongly agree). A mean score scale was constructed using the 10 items $($ Cronbach alpha $=.92)$, with a higher score on the scale indicating stronger perceptions of procedural justice (see Table 1; Appendix A also provides a full list of survey items used in this paper).

Motivational Postures. All survey items used to measure the five postures were based on Braithwaite's (2009) measures, and were all measured on five-point Likert scales $(1=$ 
Strongly disagree to $5=$ Strongly agree). Higher scores on each multi-item scale reflected higher levels of commitment, capitulation, resistance, disengagement, and game-playing, respectively. The commitment scale was measured via five items (Cronbach alpha $=.89$ ), the capitulation posture used four items (Cronbach alpha $=.62)$, resistance was measured with two items $(\text { Cronbach alpha }=.73)^{3}$, disengagement comprised three items $($ Cronbach alpha $=.80)$, and game-playing was measured with five items (Cronbach alpha $=.87$ ).

Self-reported Compliance. A measure of self-reported compliance behaviour was constructed by asking prisoners if they had breached seven common rules in the prison environment in the past 12 months. The 7-item scale was measured on a five-point Likert scale $(1=$ Never to $5=$ Most of the time; Cronbach alpha $=.88)$; all items were reverse-scored so a higher score indicates greater self-reported compliance with the rules.

Construct validity. All posturing items were subjected to a Principal Components Analysis. The analysis revealed five distinct factors with all posturing items loading onto their expected factor, and no cross-loading between items. However, a Principal Components Analysis aimed at differentiating procedural justice items from the five motivational posturing items revealed that the three capitulation items cross-loaded on the procedural justice component. To determine whether a problem of multicollinearity was present, Pearson's $r$ correlations were examined, with the highest correlation being between procedural justice and capitulation ( $r=.60, p<.001$; see Appendix B for all Pearson's r correlations). Correlations of .80 or higher are considered problematic (Field, 2009). Variance Inflation Factors (VIF) for all variables were also examined in the regression analyses to follow, with none exceeding 1.8, indicating an absence of multicollinearity between procedural justice and capitulation. Based on these results, the capitulation scale was retained for all subsequent analyses.

\footnotetext{
${ }^{3}$ Results regarding resistance should be interpreted with caution given the scale consisted of only two items.
} 
[insert Table 1 here]

\section{Results}

\section{Do motivational postures manifest in prison (RQ1)?}

In order to address Research Question 1, the Principal Components Analysis revealed that the five postures could be differentiated from each other in the prison context (See Appendix A, Table A.1). Table 1 presents prisoners' level of endorsement of each of the five motivational postures. Table 1 also presents means and standard deviations for each posture scale. Level of endorsement with each posture was calculated by dichotomising the motivational posturing scales; those who scored at or over 3.1 on the 5-point scale were seen to adopt the posture; those scoring at or below 3.0 did not adopt the posture. The posture receiving the strongest endorsement among prisoners was commitment, with $82.5 \%$ reporting they were committed. Resistance received the second strongest endorsement, with $62.5 \%$ indicating they were resistant. This was followed by capitulation $(52.0 \%$ of prisoners endorsed this posture), disengagement (23.3\% endorsement), and game-playing (15.4\% endorsement). Hence, motivational postures do exist and can be operationalised in the prison context.

\section{Is procedural justice associated with prisoners' motivational postures (RQ2a)?}

A series of five OLS Regression analyses were undertaken using the procedural justice and demographic/control variables as predictors of each posture (see Tables 2 and 3). Six demographic variables were found to be significantly associated with the postures (although each varied for each posture). These variables were age, education level, sentence type, time served, first prison sentence, and type of prison (public or private). In general, older prisoners, those with more education, and those serving their first prison sentence were less likely to adopt defiant postures. Tables 2 and 3 also show that when controlling for demographic and control variables, procedural justice was associated with each of the five postures. Of note is that 
procedural justice is positively associated with commitment and capitulation, and negatively associated with the three defiant postures. Specifically, prisoners who felt that prison staff used procedural justice within the prison were more committed and more likely to capitulate, while also being less resistant, less disengaged, and less likely to adopt a game-playing posture.

[insert Tables 2 and 3 here]

Is procedural justice associated with prisoners' self-reported compliance in prison (RQ2b)? Do motivational postures mediate the relationship between procedural justice and compliance (RQ3)?

A series of five OLS regressions were conducted using demographic/control variables, procedural justice and motivational postures as predictors of self-reported compliance behaviour. Variables were entered in two blocks (Block 1: demographics/control variables + procedural justice; Block 2: the posture) to ascertain if each posture mediated the relationship between procedural justice and self-reported compliance.

Table 4 shows the results for the models that include commitment and capitulation as predictors, Table 5 shows the results for the models that include resistance and disengagement, and Table 6 shows the results for the model that included game-playing. Across Tables 4, 5 and 6, it can be seen that three demographic/control variables were associated with prisoners' compliance: age, education, and first prison sentence. Specifically, older prisoners, those who had more education, and those who were serving their first prison term reported being more compliant. Block 1 for all models also shows that procedural justice is positively associated with self-reported compliance; prisoners who viewed prison staff as more procedurally just also reported higher levels of compliance with prison rules. 
Table 4 also shows that both commitment and capitulation were positively associated with self-reported compliance (Block 2). Hence, more committed and capitulated prisoners reported being more compliant. Tables 5 and 6 show a negative association between resistance and compliance, between disengagement and compliance and between game-playing and compliance; the more resistant or disengaged a prisoner, the less compliant they reported being, and the higher the game-playing posture, the less compliant the prisoner.

Importantly, Tables 4, 5 and 6 demonstrate that posturing can mediate the effect of procedural justice on prisoners' self-reported compliance behaviour. On entry of each of the commitment, capitulation, resistance, disengagement, and game-playing postures in Block 2, the procedural justice coefficient reduced in size from Block 1 to Block 2. For both the commitment and capitulation models, procedural justice was no longer significantly associated with self-reported compliance once the respective posture was taken into account. Five Sobel tests revealed that the reduction in the procedural justice coefficients from Block 1 to Block 2 for each of the five models was statistically significant $(z=3.58, p<.001$ for commitment model; $z=2.18, p<.05$ for capitulation model; $z=2.60, p<.01$ for resistance model; $z=2.62$, $p<.01$ for disengagement model; $z=1.82, p<.05$ for game-playing model). Together, these findings suggest that the postures of commitment and capitulation fully mediate the relationship between procedural justice and prisoners' self-reported compliance behaviour, while resistance, disengagement, and game-playing partially mediate the association between procedural justice and self-reported compliance.

[insert Tables 4, 5 and 6 about here]

\section{Discussion}

To date only a limited number of studies have examined procedural justice within a corrections context (e.g., Beijersbergen et al., 2014, 2015, 2016; Brunton-Smith \& McCarthy, 
2016; Hacin, 2018; Hacin \& Mesko, 2018; Jenness \& Calavita, 2018; Reisig \& Mesko, 2009; Weinrath, 2016). Collectively, the studies demonstrated a range of positive outcomes when prison staff are perceived as procedurally fair by prisoners. These outcomes included improved prisoner well-being, more favourable perceptions of prison staff legitimacy, and increased selfreported and actual compliance-related behaviour among prisoners (both in prison and on release from prison).

The current study extends prior research by examining, for the first time in a prison context, the applicability of Braithwaite's (2009) Theory of Defiance for understanding when and why procedural justice might influence prisoners' self-reported compliance behaviour. The findings of the current study contribute to the small but growing body of research examining procedural justice in prisons.

\section{Summary of findings}

Findings from the current study revealed that Braithwaite's (2009) five motivational postures of commitment, capitulation, resistance, disengagement and game-playing were identified in the prison setting. The postures of commitment and resistance received the strongest endorsement from prisoners. Findings also revealed that procedural justice was associated with each of the five postures, such that prisoners who felt prison staff were more procedurally just were more likely to express commitment and capitulation and were less likely to report they were resistant, disengaged or game-play prison staff. Procedural justice was also found to be related to prisoners' self-reported levels of compliance; the more procedurally just prison staff were perceived to be the more compliant prisoners reported being.

The finding that Braithwaite's postures emerged in the prison context is a new and important contribution to the literature because the postures were also found to be associated with prisoners' self-reported compliance with prison rules. Commitment and capitulation were 
related to higher levels of compliance, while resistance, disengagement and game-playing postures were associated with lower levels of compliance. Importantly, postures were found to play a mediating role in the relationship between procedural justice and self-reported compliance. Specifically, commitment and capitulation fully mediated the association between procedural justice and self-reported compliance, while resistance, disengagement and gameplaying partially mediated this relationship.

In general, the findings of the current study support previous research examining similar relationships in other regulatory contexts (e.g., Hartner et al., 2008; Murphy \& Cherney, 2012). For example, Hartner et al. (2008) found procedural justice was important for increasing commitment and capitulation and reducing resistance, disengagement and game-playing among Australian taxpayers. Murphy and Cherney (2012) found procedural justice was positively related to commitment and negatively related to resistance and disengagement when examining police-citizen interactions. Murphy (2016) also found that procedural justice was effective for reducing resistance, but had no effect on disengagement for both tax offenders and individuals involved in police-citizen interactions.

The finding that procedural justice is also associated with self-reported compliance levels in prisoners also supports prior findings from the prison literature. Beijersbergen et al. $(2014,2015)$ found that procedural justice experienced by prisoners on remand had an association with their level of compliance in prison as well as on release from prison. Where the findings of the current study extend Beijersbergen et al's findings is that they revealed the same relationship among sentenced prisoners. Reisig and Mesko (2009) also found a relationship between procedural justice and prisoners' self-reported compliance and their actual compliance behaviour.

The finding that commitment and capitulation fully mediated the relationship between procedural justice and self-reported compliance and that resistance, disengagement and game- 
playing partially mediated this relationship is also supported by prior research in non-prison contexts. Hartner et al. (2008) revealed that defiant postures mediated the relationship between procedural justice and compliance behaviour in the taxation context. Using longitudinal survey data Murphy (2016) also revealed that resistance mediated the relationship between procedural justice and self-reported compliance behaviour in both the taxation and policing contexts.

So why might postures play a mediating role in the procedural justice/compliance relationship? We suggest that procedural justice can build people's identification with authorities (Bradford, Murphy \& Jackson, 2014; Radburn, Stott, Bradford \& Robinson, 2018). Studies by Bradford et al. (2014) and Radburn et al. (2018) show that when people identify with group authorities, they more strongly relate to the attitudes and values of those authorities and will be more willing to cooperate and comply with the rules and laws that those authorities support and enforce. Posturing reflects the social distancing people wish to place between themselves and authority; so, in essence they might reflect how close or identified a person is likely to feel toward an authority. The findings from the current study suggest that posturing can be used as another way of measuring how identified people feel with the authority.

\section{Considering a regulatory enforcement pyramid for corrections}

From the preceding discussion it is clear that Braithwaite's (2009) motivational postures can be displayed within a maximum security prison environment. As such, her framework offers a useful one in which to understand prisoner behaviour in maximum security prisons, and importantly how such behaviour might be best managed. The ultimate goal of any regulator, including prison authorities, is to reinforce a deferent posture and to reduce defiant postures. Through doing so prison officers might be able to foster greater compliance with prison rules. It is suggested here that reinforcing deferent postures and reducing defiant postures might be achieved through prison staff using procedural justice in interactions with 
prisoners.

Based on our findings, we propose a regulatory compliance model that prison staff might use to identify and manage various types of prisoner behaviour. As can be seen in Figure 1, the model reflects a regulatory pyramid (Ayres \& J. Braithwaite, 1992), with both prisoner behaviour and possible sanctioning strategies depicted. The pyramid offers a graduated series of responses that can be used in a responsive manner by prison staff, escalating in regulatory intrusiveness and enforcement strategies as defiant actions increase in seriousness. Whether the proposed structure of the pyramid will work remains to be tested but is suggested here as a promising way forward.

[insert Figure 1 about here]

The bottom of the pyramid depicts the least intrusive enforcement strategies available to prison officers. The larger base signifies that the majority of prisoners are likely to be committed voluntary compliers, requiring less intrusive forms of regulation. However, the pyramid allows for officers to escalate their regulatory response as defiance levels increase. The overall goal of the regulatory pyramid is to apply downward pressure to push defiant postures into more committed postures. At the base level of the pyramid officers can display procedural justice by using respectful persuasion, negotiation, and education to communicate why an action taken by a prisoner was not appropriate and what the potential consequences may be for inappropriate actions or repeated breaches in conduct. Persuasion and education can also be used to prevent breaches from occurring in the first place.

In their study of prison officers, Liebling and Price (2011) found that 'language' rather than 'force' was the more common and effective means for flipping a tense situation to one of peace without incident. Liebling and Price argued that compliance is best achieved by focusing on 'right relationships' rather than a reliance on sanctions. This highlights the importance of 
using procedural justice at the base of the pyramid in the first instance when attempting to diffuse defiance or to prevent non-compliance.

Level two of the pyramid moves to enforced self-regulation. Here, prisoners can sometimes become non-compliant, whether through external influences or due to complacency. To encourage such prisoners to self-regulate and remain compliant, prisoners may be informed that they will be subject to random cell inspections (e.g., as a result of having previously possessed contraband). This strategy is likely to appeal to capitulated individuals as they are reluctant, but willing to follow the rules, and are particularly likely to respond at this level if they fear the repercussions/further consequences of not doing so. Those who capitulate to authority adopt a 'keep them happy' philosophy and are therefore likely to comply without requiring prison staff to escalate to a command regulation (Braithwaite, 2009, p.38). Again, procedural justice can be displayed at this level by ensuring action taken adheres to correct procedure and that interactions with prisoners are undertaken in a polite and respectful manner.

Level three of the pyramid moves to discretionary command regulation. Here, penalties may be applied, privileges revoked, and/or official reports written up for non-compliant behaviour. Disapproval of resistant (or game-playing) defiance or non-compliance is swiftly expressed by prison staff, but in a procedurally just way. For example, Liebling and Price (2011) argue that when staff use too much formal power when responding to non-compliance, resistance among prisoners can be heightened. They argue that rewards and punishments act as a "better means of persuasion" (Liebling \& Price, 2011, p.78). However, it is important that prison staff explain to prisoners why a particular decision has been reached and to provide prisoners with the opportunity to express opinions or concerns they have about the decision and subsequent action (i.e., voice). By doing so, prison staff will ensure that defiant prisoners are provided procedural justice. 
The apex of the pyramid provides the most extreme enforcement approach available to prison staff. Here use of force options and/or incapacitation can be meted out, with prisoners being sent to detention units in the most extreme case. This is a non-discretionary command regulation strategy for the most defiant and non-compliant individual. Braithwaite (2009) and Murphy (2016) suggest that domination may be required for those cases where procedural justice or less interventionist approaches fail. However, even at this most extreme level of the pyramid, the enforcement approach should still be carried out with procedural justice. Braithwaite (2009, p.88) suggests that doing so can help move those who are extremely disengaged or non-compliant down the regulatory pyramid.

Working through the lower levels prior to arriving at the peak of the pyramid may not be appropriate in all circumstances. The notion of discretion and responsiveness to the situation is important when considering how to implement a regulatory pyramid. Sparks et al. (1996), for example, highlight the importance of discretion when officers manage prisoners; they have the power to use a lot of force if required, or to "bend the rules for the right reasons" (p.155). Liebling and Price (2011) draw parallels between police and prison officers as both "make judgements about interactions by considering demeanour, gestures and language, whose content and tone is continually interpreted" (p.87). This allows for decisions to be made about how to initially approach the situation and at what point the response needs to be escalated. Furthermore, prison officers' perceptions of self-legitimacy may impact how they respond to situations. For example, Bottoms and Tankebe (2012) argued that officers who lacked selfconfidence were unable to claim credible authority, while those who were over-confident expressed "an overweening sense of power" (p.80). In a study of Slovenian prison officers, Mesko and Hacin (2018) found officers with positive perceptions of self-legitimacy were more willing to use force, suggesting they may have been over-confident in their eligibility to hold 
power. ${ }^{4}$ Mesko and Hacin further found that officer relations with colleagues influenced their willingness to use force; a subculture of comradery provides a sense of safety and "untouchability" (p.10). However, officers who perceived their supervisors as being procedurally just were less likely to use force as their supervisors did not approve of such methods, instead suggesting alternative approaches such as problem solving, communication and supervision may be more suitable for de-escalating situations. These findings suggest it is equally important to consider relationships between prison staff and their colleagues and supervisors as it is between staff and prisoners when building a framework for how officers can best manage prisoners. Upon doing so, incorporating Braithwaite's posturing styles into a regulatory pyramid may provide a more nuanced understanding of how prisoners might react to different enforcement strategies. By being responsive to the situation, prison staff can use an appropriate strategy when dealing with a prisoner, ensuring that prisoners are encouraged to voluntarily comply with their obligations in the future.

\section{Limitations and Future Research}

While the current study provides an alternative understanding for why procedural justice may be effective in a corrections context, it is not without its limitations. The current study has focused solely on four maximum security prisons in one Australian jurisdiction. Future research would benefit from extending this research into multiple Australian jurisdictions, while also considering low security prisons and work camps. Examining differences between males and females and different ethnic backgrounds should also be considered. An extension of this study could also examine the role of the prison subculture on motivational posturing styles and prisoners' compliance behaviour. The current study has also

\footnotetext{
${ }^{4}$ It should also be noted that the authors indicated use of force in Slovenian prisons is low, with unjustified and unnecessary use of force practically non-existent. As indicated in the Method section of this paper, use of force and excessive use of force complaints in prisons in this Australian jurisdiction has been on the rise, therefore it may be particularly important, in future research, to consider the role of self-legitimacy in understanding officers' decisions in how they respond to prisoners in various situations.
} 
only utilized measures of perceptions of procedural justice and self-reported compliance, which do not take into consideration actual experiences of procedural justice interactions or actual compliance behaviour. The cross-sectional design of the current study also does not allow for causation to be determined between procedural justice, motivational posturing styles and compliance behavior. Therefore, future research would benefit from a longitudinal design to capture attitudes toward prison staff and other criminal justice agents upon entry to prison, and how experiences whilst in prison potentially alter these perceptions. Longitudinal research would also be beneficial for examining the changing nature of motivational posturing styles among prisoners. Finally, the current study has only examined the use of procedural justice from the perspective of prisoners. In order for the proposed use of a regulatory pyramid to be expanded on, factors that influence prison officer responsiveness and decisions, as well as their perceptions of using procedural justice and their experiences of managing prisoners who respond differently to their directives and the prison rules should also be considered.

\section{Conclusion}

Given the involuntary confinement of those residing in prisons it is important to consider how those in such an environment react to the rules and directives they are required to follow. Braithwaite's $(2003,2009)$ Theory of Defiance is emerging in the regulation literature as a way of understanding how defiance can be manifested and how regulators can best manage defiance when it is exhibited. The current study revealed that the five motivational postures identified by Braithwaite (i.e., commitment, capitulation, resistance, disengagement, and game-playing) can be expressed in a correctional context. The findings also revealed that defiant postures are related to self-reported compliance levels and that procedural justice can be used to reduce noncompliance through the mediating influence of motivational postures. In other words, both defiant postures and non-compliance in prison can be managed effectively with procedural 
justice. Using procedural justice ensures a more humane and fair approach to maintaining order in prison. 


\section{References}

Ahmed, E., Harris, N., Braithwaite, J. \& Braithwaite, V.B. (2001). Shame management through reintegration. Cambridge: Cambridge University Press.

Ayers, I. \& Braithwaite, J. (1992). Designing responsive regulatory institutions. The Responsive Community, Summer, 41-47.

Barkworth, J. \& Murphy, K. (2015). Procedural justice policing and citizen compliance behaviour: The importance of emotion. Psychology, Crime \& Law, 21(3), 254-273. doi: 10.1080/1068316X.2014.951649

Bartel, R. \& Barclay, E. (2011). Motivational postures and compliance with environmental law in Australian agriculture. Journal of Rural Studies, 27(2), 153-170.

Beijersbergen, K.A., Dirkzwager, A.J.E., Eichelsheim, V.I., Van der Laan, P.H. \& Nieuwbeerta, P. (2014). Procedural justice and prisoners' mental health problems: A longitudinal study. Criminal Behaviour and Mental Health, 24(2), 100-112. doi: $10.1002 / \mathrm{cbm} .1881$

Beijersbergen, K.A., Dirkzwager, A.J.E., Eichelsheim, V.I., Van der Laan, P.H. \& Nieuwbeerta, P. (2015). Procedural justice, anger, and prisoners' misconduct: A longitudinal study. Criminal Justice and Behaviour, 42(2), 196-218. doi: $10.1177 / 0093854814550710$

Beijersbergen, K.A., Dirkzwager, A.J.E. \& Nieuwbeerta, P. (2016). Reoffending after release: Does procedural justice during imprisonment matter? Criminal Justice and Behavior, $43(1), 63-82$.

Bottoms, A., \& Tankebe, J. (2012). Beyond procedural justice: A dialogic approach to legitimacy in criminal justice. Journal of Criminal Law \& Criminology, 102, 119-170. 
Bradford, B., Murphy, K. \& Jackson, J. (2014). Officers as mirrors: Policing, procedural justice and the (re)production of social identity. British Journal of Criminology, 54(4), 527-550.

Braithwaite, J. (1989). Crime, shame and reintegration. New York: Cambridge University Press.

Braithwaite, J. \& Makkai, T. (1994). Trust and compliance. Policing and Society: An International Journal of Research and Policy, 4(1), 1-12. doi: $10.1080 / 10439463.1994 .9964679$

Braithwaite, J., Makkai, T. \& Braithwaite, V. (2007). Regulating aged care: Ritualism and the new pyramid. Edward Elgar Publishing, Cheltenham, UK; Northampton, MA.

Braithwaite, V. (1995). Games of engagement: Postures within the regulatory community. Law and Policy, 17(3), 225-255.

Braithwaite, V. (2001). The Community Hopes, Fears and Actions Survey: Goals and measures. Centre for Tax System Integrity Working Paper 2. Australian National University. Retrieved from http://ctsi/publications/WP/2.pdf

Braithwaite, V. (2003). Dancing with tax authorities: Motivational postures and non-compliant actions. In Braithwaite V (ed) Taxing democracy: Understanding tax avoidance and evasion. Aldershot: Ashgate, pp.15-40.

Braithwaite, V. (2009). Defiance in taxation and governance. Cheltenham, United Kingdom: Edward Elgar.

Braithwaite, V. (2013). A multipronged approach to the regulation of workplace bullying. Regulatory Institutions Network (RegNet). Occasional Paper No: 20. Canberra: Australian National University. 
Braithwaite, V., Braithwaite, J., Gibson, D. \& Makkai, T. (1994). Regulatory styles, motivational postures and nursing home compliance. Law and Policy, 16(4), 363-394.

Braithwaite, V., Murphy, K. \& Reinhart, M. (2007). Taxation threat, motivational postures, and responsive regulation. Law and Policy, 29(1), 137-158.

Brunton-Smith, I. \& McCarthy, D.J. (2016). Prison legitimacy and procedural fairness: A multilevel examination of prisoners in England and Wales. Justice Quarterly, 33(6), 1029-1054. doi 10.1080/07418825.2015.1023215

Bureau of Justice Statistics (2011). Prisoners in 2011. Retrieved from https://www.bjs.gov/index.cfm?ty=pbdetail\&iid $=4559$

Carrabine, E. (2005). Prison riots, social order and the problem of legitimacy. British Journal of Criminology, 45(6), 896-913.

Cohen, S. \& Taylor, L. (1972). Psychological survival: The experience of long-term imprisonment. Harmondsworth, United Kingdom: Penguin Books.

Crewe, B. (2007). Power, adaptation and resistance in a late-modern men's prison. The British Journal of Criminology, 47(2), 256-275. Retrieved from http://www.jstor.org/stable/23639682

Crime and Corruption Commission (2018). Taskforce Flaxton: An examination of corruption risks and corruption in Queensland prisons. Retrieved from http://www.ccc.qld.gov.au/corruption/taskforce-flaxton/taskforce-flaxton-anexamination-of-corruption-risks-in-corrective-services-facilities

Field, A. (2009). Discovering statistics using SPSS (3 ${ }^{\text {rd }}$ ed.). Thousand Oaks, CA: Sage Publications Ltd.

Gamson, W.A. (1968). Power and discontent. Homewood, IL.: The Dorsey Press. 
Goffman, E. (1961). Asylums: Essays on the social situation of mental patients. Harmondsworth, United Kingdom: Pelican.

Hacin, R. (2018). Prisoners' perceptions of legitimacy of prison staff in Slovenia. European Journal of Crime, Criminal Law and Criminal Justice, 26(2), 160-181. doi: $10.1163 / 15718174-02602003$

Hacin, R. \& Meško, G. (2018). Prisoners' perception of legitimacy of the prison staff: A qualitative study in Slovene prisons. International Journal of Offender Therapy and Comparative Criminology, 62(13), 4332-4350. doi: 10.1177/0306624X18758896

Harris, N. \& Gosnell, L. (2012). From the perspective of parents: Interviews following a child protection investigation. Regulatory Institutions Network (RegNet). Occasional Paper No: 18. Canberra: Australian National University.

Hartner, M., Rechberger, S., Kirchler, E. \& Schabmann, A. (2008). Procedural fairness and tax compliance. Economic Analysis and Policy, 38(1), 137-152.

Herbert, S. (2006). Tangled up in blue: Conflicting paths to police legitimacy. Theoretical Criminology, 10(4), 481-504.

Jackson, J., Bradford, B., Hough, M., Myhill, A., Quinton, P. \& Tyler, T.R. (2012). Why do people comply with the law? Legitimacy and the influence of legal institutions. British Journal of Criminology, 52(6), 1051-1071.

Jackson, J., Tyler, T.R., Bradford, B., Taylor, D. \& Shiner, M. (2010). Legitimacy and procedural justice in prisons. Prison Service Journal, 191, 4-10.

Jenness, V. \& Calavita, K. (2018). It depends on the outcome: Prisoners, grievances, and perceptions of justice. Law \& Society Review, 52(1), 41-71. 
Liebling, A. assisted by Arnold, H. (2004). Prisons and their moral performance: A study of values, quality, and prison life. Oxford: Oxford University Press.

Liebling, A. \& Price, D. (2011). Prison officers and the use of discretion. In L. Gelsthorpe \& N. Padfield (Eds.), Exercising discretion: Decision-making in the criminal justice system and beyond (pp. 74-96). New York, NY: Routledge.

Madon, N.S., Murphy, K. \& Sargeant, E. (2017). Promoting police legitimacy among disengaged minority groups: Does procedural justice matter more? Criminology \& Criminal Justice, 17(5), 624-642.

Mazerolle, L., Sargeant, E., Cherney, A., Bennett, S., Murphy, K., Antrobus, E. \& Martin, P. (2014). Procedural justice and legitimacy in policing. New York: Springer.

McDermott, K. \& King, R.D. (1988). Mind games: Where the action is in prisons. British Journal of Criminology, 28(3), 357-377.

McIlwain, G.B. (2004). Professional misconduct between inmates and non-custodial staff: A study of Queensland's correctional centres. PhD Thesis, Griffith University, Brisbane, Australia.

Mesko, G. \& Hacin, R. (2018). Self-legitimacy and use of force: A quantitative study of prison officers in Slovenia. International Journal of Comparative and Applied Criminal Justice. Advance online publication. doi: 10.1080/01924036.2018.1543128

Murphy, K. (2003). Procedural justice and tax compliance. Australian Journal of Social Issues. $38(3), 379-408$.

Murphy, K. (2005). Regulating more effectively: The relationship between procedural justice, legitimacy and tax non-compliance. Journal of Law and Society, 32(4), 562-589. 
Murphy, K. (2008). Enforcing tax compliance: To punish or persuade? Economic Analysis and Police, 38(1), 113-135.

Murphy, K. (2016). Turning defiance into compliance with procedural justice: Understanding reactions to regulatory encounters through motivational posturing. Regulation and Governance, 10, 93-106. doi: 10.1111/rego.12073

Murphy, K. (2017). Challenging the 'invariance' thesis: Procedural justice policing and the moderating influence of trust on citizens' obligation to obey police. Journal of Experimental Criminology, 13, 429-437. doi: 10.1007/s11292-017-9298-y

Murphy, K. \& Cherney. A. (2011). Fostering cooperation with the police: How do ethnic minorities in Australia respond to procedural justice-based policing? Australian and New Zealand Journal of Criminology, 44(2), 235-257.

Murphy, K. \& Cherney, A. (2012). Understanding cooperation with police in a diverse society. British Journal of Criminology, 52, 181-201. doi: 10.1093/bjc/azr065

Murphy, K., Mazerolle, L. \& Bennett, S. (2014). Promoting trust in police: Findings from a randomised experimental field trial of procedural justice policing. Policing and Society, 24(4), 405-424.

Murphy, K., Murphy, B. \& Mearns, M. (2010). 'The 2009 crime, safety, and policing in Australia survey': Survey methodology and preliminary findings. Alfred Deakin Research Institute Working Paper No. 17. Geelong, NSW: Deakin University.

Murphy, K. \& Tyler, T. (2008). Procedural justice and compliance behaviour: The mediating role of emotions. European Journal of Social Psychology, 38, 652-668. doi: 10.1002/ejsp.502 
Murphy, K., Tyler, T.R. \& Curtis, A. (2009). Nurturing regulatory compliance: Is procedural justice effective when people question the legitimacy of the law? Regulation \& Governance, 3(1), 1-26.

Radburn, M., Stott, C., Bradford, B. \& Robinson, M. (2018). When is policing fair? Groups, identity and judgements of the procedural justice of coercive crowd policing. Policing and Society, 28, 647-664.

Reisig, M.D. \& Mesko, G. (2009). Procedural justice, legitimacy and prisoner misconduct. Psychology, Crime \& Law, 15(1), 41-59. doi: 10.1080/10683160802089768

Sargeant, E., Murphy, K. \& Cherney, A. (2014). Ethnicity, trust and cooperation with police: Testing the dominance of the process-based model. European Journal of Criminology, 11(4), 500-524. doi: 10.1177/1477370813511386

Sargeant, E., Murphy, K. \& Madon, N. (2018). Is dissatisfaction with police inevitable? Testing an integrated model of motivational postures and procedural justice in police-citizen contacts. Police Practice and Research: An International Journal, 19(2), 125-137. doi: $10.1080 / 15614263.2018 .1418156$

Scraton, P., Sim, J. \& Skidmore, P. (1991). Prisons under protest. Buckingham: Open University Press.

Sherman, L.W. (1993). Defiance, deterrence, and irrelevance: A theory of the criminal sanction. Journal of Research in Crime and Delinquency, 30(4), 445-473. doi: $10.1177 / 0022427893030004006$

Sparks, R., Bottoms, A. \& Hay, W. (1996). Prisons and the problem of order. Oxford, United Kingdom: Clarendon.

Terrill, W. (2003). Police use of force and suspect resistance: The micro process of the policesuspect encounter. Police Quarterly, 6(1), 51-83. 
Tyler, T.R. (1990). Why people obey the law. New Haven: Yale University Press.

Tyler, T.R. (2006). Why people obey the law. New Jersey: Princeton University Press.

Tyler, T.R. \& Huo, Y.J. (2002). Trust in the law. New York: Russell-Sage.

Tyler, T.R. \& Lind, E.A. (1992). A relational model of authority in groups. Advances in Experimental Social Psychology, 25, 115-191.

Weinrath, M. (2016). Behind the walls: Inmates and Correctional Officers on the state of Canadian prisons. UBC Press, Law \& Society Series.

Weitzer, R. (2006). Race and policing in America: Conflict and reform. New York: Cambridge University Press.

Weitzer, R. \& Brunson, R.K. (2009). Strategic responses to the police among inner-city youth. Sociological Quarterly, 50, 235-256.

Wooldredge, J. D. (1999). Inmate experiences and psychological well-being. Criminal Justice and Behavior, 26(2), 235-250. doi: 10.1177/0093854899026002005 


\section{Appendix A}

\section{Procedural Justice}

Staff in this prison take account of the needs and concerns of the prisoners they deal with

Staff try to be fair when making decisions

Staff listen to prisoners before making decisions

Staff give prisoners the opportunity to tell their side of the story before decisions are made

Staff in this prison treat prisoners with respect and dignity

Staff are always polite when dealing with prisoners

Staff address and talk to me in a respectful manner

Staff in this prison show concern and understanding towards me

\section{Motivational Postures}

\section{Commitment}

I feel I should follow the rules and procedures of prison (Comm1)

Obeying prison rules and procedures is the right thing to do (Comm2)

Following prison rules and procedures should be willingly accepted by all inmates (Comm3)

Overall, I am committed to doing the right thing by staff (Comm4)

Obeying prison procedures ultimately advantages everyone (Comm5)

\section{Capitulation}

Even if staff find I am doing something wrong, they will still respect me (Cap1)

If you cooperate with staff, they are likely to be respectful toward you (Cap2)

The way this prison works may not be perfect but it works well enough for most of us (Cap3)

\section{Resistance}

More inmates need to stand up to staff if they treat us poorly (Resist1)

It's important not to let staff push you around (Resist2)

Disengagement

I don't care if I am not doing the right thing by staff in this prison (Diseng1)

I personally don't think there is much that can happen to me if I choose to disobey prison rules (Diseng2)

If I find out I am not obeying prison rules, I'm not going to lose any sleep over it (Diseng3)

Game-playing

I like the game of finding the grey area of prison rules (GP1)

I enjoy talking to my mates in here about loopholes in the prison system (GP2)

I enjoy the challenge of finding ways not to follow rules (GP3)

I look for ways to manipulate staff (GP4)

I enjoy spending time working out how changes in prison rules and procedures will affect me (GP5)

\section{Self-reported Compliance with prison rules}

In this prison (in the last 12 months), how often have you...

...damaged property that did not belong to you

...used violence against another inmate

...refused to obey an order given by a member of the prison staff

...threatened another inmate with violence

...possessed tobacco (after May 2014)

...possessed contraband, such as drugs, weapons or money

....taken property that did not belong to you 
Table A.1

Factor analysis differentiating motivational posturing items

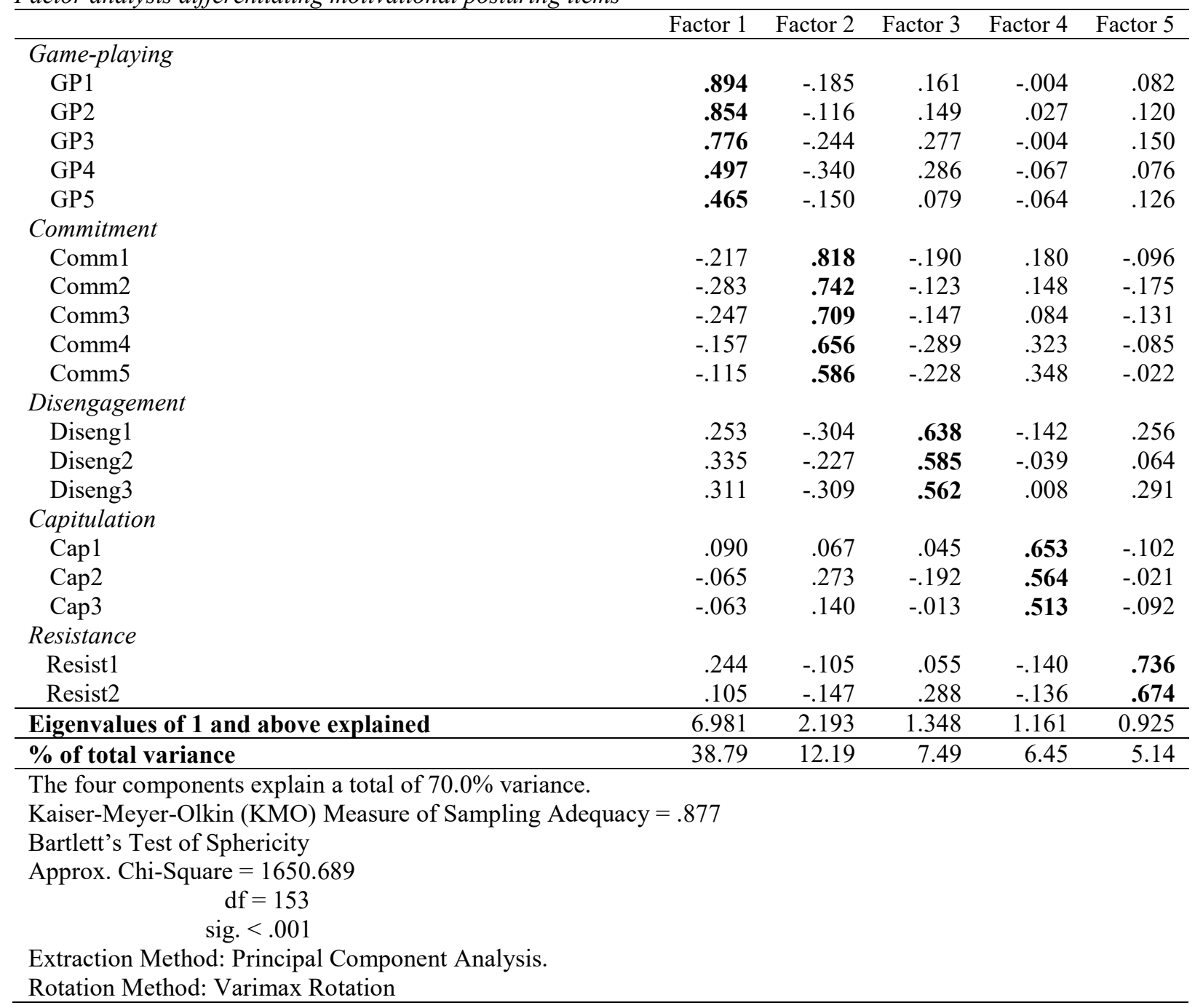




\section{Appendix B}

Table B.1

Pearson's Bivariate Correlation of all variables

\begin{tabular}{|c|c|c|c|c|c|c|c|}
\hline & PJ & Comm. & Cap. & Resist. & Diseng. & G-P & $\begin{array}{l}\text { S-R } \\
\text { Comp. }\end{array}$ \\
\hline Procedural Justice (PJ) & 1 & $.350 * * *$ & $.601 * * *$ & $-.381 * * *$ & $-.283 * * *$ & $-.204 * *$ & $.299 * * *$ \\
\hline Commitment (Comm.) & & 1 & $.558 * * *$ & $-.356 * * *$ & $-.572 * * *$ & $-.494 * * *$ & $.548 * * *$ \\
\hline Capitulation (Cap.) & & & 1 & $-.294 * * *$ & $-.323 * * *$ & $-.219 * * *$ & $.350 * * *$ \\
\hline Resistance (Resist.) & & & & 1 & $.466 * * *$ & $.372 * * *$ & $-.442 * * *$ \\
\hline Disengagement (Diseng.) & & & & & 1 & $.591 * * *$ & $-.517 * * *$ \\
\hline Game-playing (G-P) & & & & & & 1 & $-.469 * * *$ \\
\hline Self-reported Compliance (S-R Comp) & & & & & & & 1 \\
\hline
\end{tabular}

$* p<.05 ; * * p<.01 ; * * * p<.001$ (2-tailed) 
Descriptive statistics for all variables of interest (study sample compared to full jurisdiction prison population)

\begin{tabular}{|c|c|c|c|c|}
\hline & \multicolumn{2}{|c|}{$\begin{array}{l}\text { STUDY SAMPLE } \\
(N=177)\end{array}$} & \multicolumn{2}{|c|}{$\begin{array}{l}\text { JURISDICTION } \\
(N=7,746)\end{array}$} \\
\hline & Mean (SD) & $\%$ & Mean (SD) & $\%$ \\
\hline Age & $38.91(11.15)$ & & 35.00 (NA) & \\
\hline \multicolumn{5}{|l|}{ Ethnicity } \\
\hline Non-Indigenous Australian & & 72.3 & & 68.2 \\
\hline Indigenous Australian / Other & & 27.7 & & 31.8 \\
\hline Education & $1.48(0.65)$ & & NA & \\
\hline Year 12 or lower & & 60.2 & & \\
\hline Cert. 1 - Adv. Diploma & & 31.3 & & \\
\hline Bachelor Degree or higher & & 8.5 & & \\
\hline Marital Status & & & NA & \\
\hline Married / De facto & & 18.6 & & \\
\hline Single / Divorced / Widowed & & 81.4 & & \\
\hline \multicolumn{5}{|l|}{ Sentenced } \\
\hline Yes & & 91.5 & & 70.7 \\
\hline No (on remand) & & 8.5 & & 29.3 \\
\hline Time Served & $1.39(0.62)$ & & NA & \\
\hline$<5$ years & & 69.0 & & \\
\hline $5-15$ years & & 23.5 & & \\
\hline $15+$ years & & 7.5 & & \\
\hline \multicolumn{5}{|l|}{ First time in prison } \\
\hline Yes & & 37.3 & & 36.2 \\
\hline No & & 62.7 & & 63.9 \\
\hline Procedural Justice & $2.78(0.73)$ & & NA & \\
\hline Commitment & $3.80(0.68)$ & 82.5 & NA & \\
\hline Capitulation & $3.31(0.63)$ & 52.0 & NA & \\
\hline Resistance & $3.56(0.80)$ & 62.5 & NA & \\
\hline Disengagement & $2.63(0.83)$ & 23.3 & NA & \\
\hline Game-playing & $2.48(0.75)$ & 15.4 & NA & \\
\hline Self-reported Compliance & $4.21(0.28)$ & & NA & \\
\hline
\end{tabular}

*Jurisdictional Prisons data taken from ABS (2016) - comparative to the time most survey data was collected Note: NA = Official data is not available for this variable 
Table 2

OLS regression analyses exploring procedural justice and demographic/control variables as predictors of each motivational posture

\begin{tabular}{|c|c|c|c|c|c|c|}
\hline \multirow[b]{2}{*}{ Predictor } & \multicolumn{3}{|c|}{ Commitment } & \multicolumn{3}{|c|}{ Capitulation } \\
\hline & $\boldsymbol{B}$ & $S E_{B}$ & $\beta$ & $\boldsymbol{B}$ & $S E_{B}$ & $\beta$ \\
\hline Age & .014 & .004 & $.229 * *$ & .003 & .004 & .046 \\
\hline $\begin{array}{l}\text { Ethnicity }(0=\text { Indigenous; } \\
1=\text { Non-Indigenous })\end{array}$ & .101 & .104 & .067 & .111 & .086 & .079 \\
\hline Education & .062 & .024 & $.183 * *$ & .023 & .020 & .073 \\
\hline $\begin{array}{l}\text { Marital Status } \\
(0=\text { Unmarried; } 1=\text { Married })\end{array}$ & .179 & .120 & .103 & .132 & .100 & .081 \\
\hline $\begin{array}{l}\text { Sentence Type } \\
(0=\text { Sentenced; } 1=\text { Remand })\end{array}$ & -.213 & .172 & -.088 & -.313 & .143 & $-.138 *$ \\
\hline Time Served & -.001 & .035 & .002 & -.065 & .029 & $-.157 *$ \\
\hline $\begin{array}{l}\text { First Time in Prison }(0=\mathrm{No} \text {; } \\
1=\text { Yes })\end{array}$ & .181 & .095 & .129 & .102 & .079 & .078 \\
\hline $\begin{array}{l}\text { Prison Type }(0=\text { Private; } \\
1=\text { Public })\end{array}$ & .251 & .140 & .132 & -.267 & .116 & $-.150 *$ \\
\hline Procedural Justice & .303 & .064 & $.329 * * *$ & .509 & .053 & $.590 * * *$ \\
\hline Constant & -1.169 & .258 & & .081 & .214 & \\
\hline$R^{2}$ & & .288 & & & .439 & \\
\hline$F$ & & $7.273 * * *$ & & & $14.068 * * *$ & \\
\hline$d f$ & & 9,162 & & & 9,162 & \\
\hline
\end{tabular}

${ }^{*} p<.05 ;{ }^{* *} p<.01 ;{ }^{* * *} p<.001$ 
Table 3

OLS regression analyses exploring procedural justice and demographic/control variables as predictors of each motivational posture

\begin{tabular}{|c|c|c|c|c|c|c|c|c|c|}
\hline \multirow[b]{2}{*}{ Predictor } & \multicolumn{3}{|c|}{ Resistance } & \multicolumn{3}{|c|}{ Disengagement } & \multicolumn{3}{|c|}{ Game-playing } \\
\hline & B & $S E_{B}$ & $\beta$ & B & $S E_{B}$ & $\boldsymbol{\beta}$ & B & $S E_{B}$ & $\beta$ \\
\hline Age & -.016 & .005 & $-.220 * *$ & -.023 & .006 & $-.307 * * *$ & -.021 & .005 & $-.311 * * *$ \\
\hline $\begin{array}{l}\text { Ethnicity ( } 0=\text { Indigenous; } \\
1=\text { Non-Indigenous })\end{array}$ & -.076 & .121 & -.043 & -.015 & .135 & -.008 & .032 & .123 & .019 \\
\hline Education & -.004 & .028 & -.009 & -.056 & .031 & -.134 & -.064 & .028 & $-.171 *$ \\
\hline $\begin{array}{l}\text { Marital Status } \\
(0=\text { Unmarried; } 1=\text { Married })\end{array}$ & .159 & .140 & .078 & -.079 & .156 & -.037 & -.104 & .142 & -.054 \\
\hline $\begin{array}{l}\text { Sentence Type } \\
(0=\text { Sentenced; } 1=\text { Remand })\end{array}$ & .074 & .201 & .026 & .015 & .223 & .005 & .093 & .203 & .035 \\
\hline Time Served & .037 & .041 & .071 & .022 & .045 & .040 & .003 & .041 & .006 \\
\hline $\begin{array}{l}\text { First Time in Prison }(0=\mathrm{No} \\
1=\text { Yes })\end{array}$ & -.505 & .111 & $-.307 * * *$ & -.129 & .123 & -.075 & -.040 & .112 & -.026 \\
\hline $\begin{array}{l}\text { Prison Type }(0=\text { Private; } \\
1=\text { Public) }\end{array}$ & .053 & .164 & .024 & -.061 & .182 & -.026 & -.097 & .166 & -.046 \\
\hline Procedural Justice & -.347 & .075 & $-.320 * * *$ & -.254 & .083 & $-.224 * *$ & -.151 & .076 & $-.148 *$ \\
\hline Constant & .677 & .301 & & 1.188 & .335 & & 1.166 & .305 & \\
\hline$R^{2}$ & & .300 & & & .203 & & & .182 & \\
\hline$F$ & & $7.703 * * *$ & & & $4.587 * * *$ & & & $4.005 * * *$ & \\
\hline$d f$ & & 9,162 & & & 9,162 & & & 9,162 & \\
\hline
\end{tabular}


Table 4


compliance

\begin{tabular}{|c|c|c|c|c|c|c|c|c|c|c|c|c|}
\hline \multirow[b]{3}{*}{ Predictor } & \multicolumn{6}{|c|}{ Model 1 (Commitment) } & \multicolumn{6}{|c|}{ Model 2 (Capitulation) } \\
\hline & \multicolumn{3}{|c|}{ Block 1} & \multicolumn{3}{|l|}{ Block 2} & \multicolumn{3}{|c|}{ Block 1} & \multicolumn{3}{|l|}{ Block 2} \\
\hline & $\boldsymbol{B}$ & $S E_{B}$ & $\beta$ & $B$ & $S E_{B}$ & $\beta$ & $\boldsymbol{B}$ & $S E_{B}$ & $\beta$ & $\boldsymbol{B}$ & $S E_{B}$ & $\beta$ \\
\hline Age & .007 & .001 & $.344 * * *$ & .005 & .001 & $.254 * * *$ & .007 & .001 & $.344 * * *$ & .007 & .001 & $.335 * * *$ \\
\hline $\begin{array}{l}\text { Ethnicity ( } 0=\text { Indigenous; } \\
1=\text { Non-Indigenous })\end{array}$ & .029 & .033 & .060 & .017 & .030 & .034 & .029 & .033 & .060 & .022 & .033 & .045 \\
\hline Education & .017 & .007 & $.155^{*}$ & .009 & .007 & .083 & .017 & .007 & $.155 \%$ & .015 & .007 & $.141 *$ \\
\hline $\begin{array}{l}\text { Marital Status } \\
(0=\text { Unmarried; } 1=\text { Married })\end{array}$ & .021 & .038 & .039 & -.001 & .035 & -.002 & .021 & .038 & .039 & .013 & .038 & .023 \\
\hline $\begin{array}{l}\text { Sentence Type } \\
(0=\text { Sentenced; } 1=\text { Remand })\end{array}$ & .060 & .054 & .077 & .087 & .050 & .112 & .060 & .054 & .077 & .081 & .054 & .104 \\
\hline Time Served & -.002 & .011 & -.011 & -.002 & .010 & -.011 & -.002 & .011 & -.011 & .003 & .011 & .020 \\
\hline $\begin{array}{l}\text { First Time in Prison }(0=\mathrm{No} \text {; } \\
1=\text { Yes })\end{array}$ & .101 & .030 & $.225 * * *$ & .078 & .028 & $.175 * *$ & .101 & .030 & $.225 * * *$ & .094 & .030 & $.210 * *$ \\
\hline $\begin{array}{l}\text { Prison Type }(0=\text { Private; } \\
1=\text { Public })\end{array}$ & -.003 & .044 & -.005 & -.035 & .041 & -.057 & -.003 & .044 & -.005 & .015 & .044 & .024 \\
\hline Procedural Justice & .065 & .020 & $.220 * *$ & .027 & .020 & .090 & .065 & .020 & $.220 * *$ & .031 & .025 & .105 \\
\hline Commitment & - & - & - & .126 & .023 & $.392 * * *$ & - & - & - & - & - & - \\
\hline Capitulation & - & - & - & - & - & - & - & - & - & .067 & .030 & $.194 *$ \\
\hline Constant & .394 & .081 & & .541 & .080 & & .394 & .081 & & .388 & .060 & \\
\hline$R^{2}$ & & .312 & & & .422 & & & .312 & & & .333 & \\
\hline$R^{2} \Delta$ & & .312 & & & .110 & & & .312 & & & .021 & \\
\hline$F$ & & $8.160^{\circ}$ & & & $30.527 * * *$ & & & $8.160^{\circ}$ & & & $5.108 *$ & \\
\hline$d f$ & & 9,162 & & & 1,161 & & & 9,162 & & & 1,161 & \\
\hline
\end{tabular}


Table 5

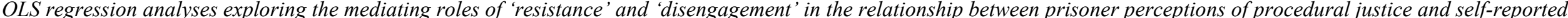
compliance

\begin{tabular}{|c|c|c|c|c|c|c|c|c|c|c|c|c|}
\hline \multirow[b]{3}{*}{ Predictor } & \multicolumn{6}{|c|}{ Model 3 (Resistance) } & \multicolumn{6}{|c|}{ Model 4 (Disengagement) } \\
\hline & \multicolumn{3}{|c|}{ Block 1 } & \multicolumn{3}{|l|}{ Block 2} & \multicolumn{3}{|c|}{ Block 1} & \multicolumn{3}{|l|}{ Block 2} \\
\hline & $\boldsymbol{B}$ & $S E_{B}$ & $\beta$ & $\boldsymbol{B}$ & $S E_{B}$ & $\boldsymbol{\beta}$ & $B$ & $S E_{B}$ & $\boldsymbol{\beta}$ & $\boldsymbol{B}$ & $S E_{B}$ & $\beta$ \\
\hline Age & .007 & .001 & $.344 * * *$ & .006 & .001 & $.290 * * *$ & .007 & .001 & $.344 * * *$ & .005 & .001 & $.236 * * *$ \\
\hline $\begin{array}{l}\text { Ethnicity ( } 0=\text { =ndigenous; } \\
1=\text { Non-Indigenous })\end{array}$ & .029 & .033 & .060 & .024 & .032 & .050 & .029 & .033 & .060 & .028 & .030 & .058 \\
\hline Education & .017 & .007 & $.155 *$ & .017 & .007 & $.153 *$ & .017 & .007 & $.155 *$ & .012 & .007 & .108 \\
\hline $\begin{array}{l}\text { Marital Status } \\
(0=\text { Unmarried; } 1=\text { Married })\end{array}$ & .021 & .038 & .039 & .032 & .037 & .057 & .021 & .038 & .039 & .014 & .035 & .026 \\
\hline $\begin{array}{l}\text { Sentence Type } \\
(0=\text { Sentenced; } 1=\text { Remand })\end{array}$ & .060 & .054 & .077 & .065 & .053 & .084 & .060 & .054 & .077 & .062 & .050 & .079 \\
\hline Time Served & -.002 & .011 & -.011 & .001 & .011 & .007 & -.002 & .011 & -.011 & .000 & .010 & .003 \\
\hline $\begin{array}{l}\text { First Time in Prison }(0=\mathrm{No} \text {; } \\
1=\text { Yes })\end{array}$ & .101 & .030 & $.225 * * *$ & .068 & .031 & $.151 *$ & .101 & .030 & $.225 * * *$ & .089 & .028 & $.199 * *$ \\
\hline $\begin{array}{l}\text { Prison Type }(0=\text { Private; } \\
1=\text { Public })\end{array}$ & -.003 & .044 & -.005 & .000 & .043 & .001 & -.003 & .044 & -.005 & -.009 & .041 & -.014 \\
\hline Procedural Justice & .065 & .020 & $.220 * *$ & .042 & .021 & $.142 *$ & .065 & .020 & $.220 * *$ & .042 & .019 & $.141 *$ \\
\hline Resistance & - & - & - & - & - & - & - & - & - & -.091 & .018 & $-.349 * * *$ \\
\hline Disengagement & - & - & - & -.066 & .021 & $-.243 * *$ & - & - & - & - & - & - \\
\hline Constant & .394 & .081 & & .439 & .080 & & .394 & .081 & & .502 & .079 & \\
\hline$R^{2}$ & & .312 & & & .353 & & & .312 & & & .409 & \\
\hline$R^{2} \Delta$ & & .312 & & & .041 & & & .312 & & & .097 & \\
\hline$F$ & & $8.160 * * *$ & & & $10.319 * *$ & & & $8.160 * * *$ & & & $26.446 * * *$ & \\
\hline$d f$ & & 9,162 & & & 1,161 & & & 9,162 & & & 1,161 & \\
\hline
\end{tabular}


Table 6

OLS regression analyses exploring the mediating roles of 'game-playing' in the relationship between prisoner perceptions of procedural justice and self-reported compliance

\begin{tabular}{|c|c|c|c|c|c|c|}
\hline \multirow[b]{3}{*}{ Predictor } & \multicolumn{6}{|c|}{ Model 3 (Game-playing) } \\
\hline & \multicolumn{3}{|c|}{ Block 1} & \multicolumn{3}{|l|}{ Block 2} \\
\hline & $\boldsymbol{B}$ & $S E_{B}$ & $\boldsymbol{\beta}$ & $\boldsymbol{B}$ & $S E_{B}$ & $\boldsymbol{\beta}$ \\
\hline Age & .007 & .001 & $.344 * * *$ & .005 & .001 & $.246 * * *$ \\
\hline $\begin{array}{l}\text { Ethnicity }(0=\text { Indigenous; } \\
1=\text { Non-Indigenous })\end{array}$ & .029 & .033 & .060 & .032 & .031 & .067 \\
\hline Education & .017 & .007 & $.155 *$ & .011 & .007 & .101 \\
\hline $\begin{array}{l}\text { Marital Status ( } 0=\text { Unmarried; } \\
1=\text { Married) }\end{array}$ & .021 & .038 & .039 & .012 & .036 & .022 \\
\hline $\begin{array}{l}\text { Sentence Type }(0=\text { Sentenced; } \\
1=\text { Remand })\end{array}$ & .060 & .054 & .077 & .069 & .051 & .088 \\
\hline Time Served & -.002 & .011 & -.011 & -.001 & .010 & -.009 \\
\hline $\begin{array}{l}\text { First Time in Prison }(0=\mathrm{No} ; \\
1=\text { Yes })\end{array}$ & .101 & .030 & $.225 * * *$ & .097 & .028 & $.217 * * *$ \\
\hline $\begin{array}{l}\text { Prison Type }(0=\text { Private; } \\
1=\text { Public })\end{array}$ & -.003 & .044 & -.005 & -.012 & .042 & -.019 \\
\hline Procedural Justice & .065 & .020 & $.220 * *$ & .051 & .019 & $.173 * *$ \\
\hline Game-playing & - & - & - & -.091 & .020 & $-.314 * * *$ \\
\hline Constant & .394 & .081 & & .500 & .080 & \\
\hline$R^{2}$ & & .312 & & & .393 & \\
\hline$R^{2} \Delta$ & & .312 & & & .081 & \\
\hline$F$ & & 8.160 & & & $21.432 * * *$ & \\
\hline$d f$ & & 9,162 & & & 1,161 & \\
\hline
\end{tabular}

$* p<.05 ; * * p<.01 ; * * * p<.001$ 


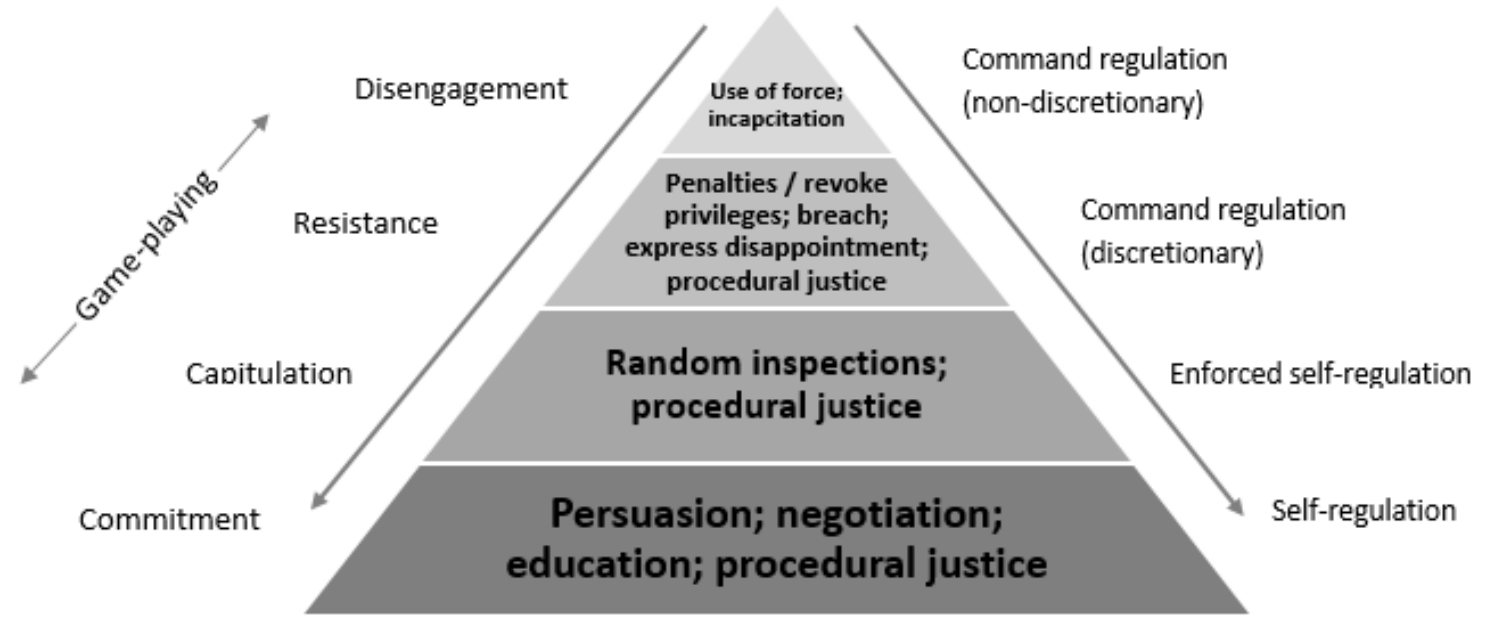

MOTIVATIONAL POSTURES

ENFORCEMENT STRATEGIES

REGULATORY STRATEGIES

Figure 1. A regulatory enforcement pyramid applied to the corrections context 